\title{
A political corrida. Spanish-Catalan parallels
}

\section{Introduction}

Corrida de toros ${ }^{1}$ is a complementary element of tauromachic tradition, i.e. a broad category of spectacles, participated by bulls, during which the human takes the fight with a wild animal. At present, despite the enacting of these types of spectacles in a few countries in the world, they are ultimately recognized as the symbol of Spain. Corrida constitutes a unique tradition, which should be considered in a broader context, not only socio-cultural, but also political. The existing discourse in public space covering this issue indicates strong links between political decisions and tauromachic performances; what is more noticeable is the intensification of exposure between them in mass media, both of a regional and national nature. Their presence is strongly marked in literature (not only scientific) and on the Internet. In the case of Catalonia, the aspect of a sense of separate identity, including attachment to one's own symbols, has become particularly important in this context. The importance of ever-lively discussion on the banning of the spectacle in Spain also needs to be emphasized.

Undeniably, for centuries corrida has become part of Spanish culture, and its systematization, careful definition of rules and principles, as well as the impact on society over decades makes it possible to attribute the role and significance to the spectacle similar to today's nation-specific sports. Furthermore, both in Catalonia and other regions of Spain corrida de toros took the form of modern sport with the participation of spectators only from the beginning of the $19^{\text {th }}$ century, and a century later it became a major attraction in the community. It was almost as popular as football today. Adopting this perception of the corrida permits to recognize it as an idea-based game of agon, which focuses on the individual predispositions of players and compliance with the rules of the game, and victory becomes an objective good (Caillois, 1997). At the same time, such a metaphysical message illustrates the eternal idea of struggle.

\footnotetext{
${ }^{1}$ A literal translation of the term would indicate a fight on the area of the bulls themselves, while the essence of the show lies in the competition - the fight of a bull with a man. Therefore, in the article I use the original Spanish name, i.e.. corrida de toros or its abbreviated form - corrida.

* Correspondence address: Instytut Nauk o Polityce i Administracji, Uniwersytet Zielonogórski, Wojska Polskiego 69, 65-762 Zielona Góra, Polska, e-mail: whusar@uz.zgora.pl.
} 
The aim of the article is to analyze the issues of delegalization of corrida de toros in Catalonia in 2010 in the context of the Spanish-Catalan conflict. The study is seeking an answer to the question of whether the decision to delegate the corrida by Catalan decision-makers was politically motivated, i.e. became the next level of competition on the Catalonia-Spain line, or whether it was dictated by considerations aimed at protecting animal rights. Furthermore, an important element of exploration will be the analysis of central government activities in the field of tauromachic traditions (including in particular the case law of the Constitutional Court in Spain). In this context, particularly useful will be the analysis of content, comparative and decision-making method, as well as institutional and legal method.

The issue of the delegalization of the bullfighting spectacle in Spain discussed in this article is not only important in the socio-cultural sense, but at the same time it is gaining great significance in the aspect of political action, especially in the era of radicalization of Catalan independentism, becoming another conflict-causing factor. In line with the above, the identification of motives for action by Catalan and Spanish (central) decision-makers is becoming key to seeking consensus in the matter of corrida de toros.

\section{Corrida de toros in Spain}

The beginnings of tauromachia in Spain date back several centuries. The spectacle appears during the expansion of the Roman empire and is the fruit of the interpenetration of cultural content, and thus the acquisition and implementation of many traditions and customs drawn from the achievements of other cultures. In the case we are interested in, the territorial and cultural expansion of the Romans implied the drawing of tauromachic traditions from the circle of Greek culture ${ }^{2}$ and transferring it to the land of the Iberian Peninsula. Julius Caeser himself was to be its main initiator and loyal herald. However, there is no shortage of researchers looking for roots of the corrida in Spain alone. Cristóbal Lozano pointed to its sources during the games of carpenos, which de facto dated back to the Roman circenses (Daza, 1999: 28). Built on the model of Roman amphitheatres, plazas de toros would also confirm the ancient roots of bullfighting.

There is also disagreement as to whether or not appearance on the Peninsula of the corrida was the work of an Arab or maybe European civilization, because it is difficult to underestimate the contribution of the Moors in the formation of culture and customs in Spain, drawn from the traditions of the population living in the northern regions of Africa, where the fight against wild animals, including bulls, was popular (ZiółkowskaKuflińska, 2017: 55). This cited stance may also sanction the reluctance of Catholic kings towards the corrida, considering it to be associated with the Moorish culture. On the other hand, hunting for wild bulls ${ }^{3}$, followed by attempts to domesticate and breed

${ }^{2}$ Crete is considered to be the original place to practice bullfighting habits, which was reflected in the famous Greek myth of Minos, King of Crete.

3 These animals were a symbol of strength and power not only in religious beliefs of a primitive nature, 
them, were important determinants. In addition, it is believed that the first tauromachic spectacle took place as early as 815 , and its initiators were Christians; but it took place in the city of León (Ziółkowska-Kuflińska, 2017: 54), which was under Arabic influence at the time. Interpretative difficulties are also compounded by the fact that the corrida was known both in areas under the influence of Arab culture, i.e. southern Spain, and the northwestern part of the Iberian Peninsula, where Christianity religion dominated.

As a construct subjected to modification over the centuries, corrida de toros gained popularity among Spaniards in the Middle Ages, when horse riders chased away bulls scattered over huge tracts of land, striking them with long peaks, with the applause of a spontaneously gathered audience. These $12^{\text {th }}$-century bull races found their continuation in knightly tournaments (starting in the $13^{\text {th }}$ century). Knights deriving from of Spanish noble families fought the bull considered a noble animal at that time. Tournaments were graced with the most important historical events, victories in wars, religious holidays or e.g. royal marriage. One of the first mentions of bullfighting in Catalonia dates back to the $14^{\text {th }}$ century, when as a spectacle it graced the meeting of the kings of France and Aragon to develop a common position in support of Clement VII (anti-pope) (Tkac, 2014: 146).

Over time, the interest of notables in the corrida decreased and it became an entertainment for the people's pleasures, which meant that the participant in the fight stopped moving horseback and the fight with the animal was on foot (Barbarzak, 2016: 21) ${ }^{4}$. In this way, from the chaotic struggles of the crowd with the wild bull corrida de toros evolved into organized, regulated contest, largely reminiscent of sports competitions. Its transformation was influenced by social, cultural and economic, as well as political factors.

The importance and impact of the corrida on the population of the Peninsula is largely illustrated by legal acts related to it issued by both kings ${ }^{5}$ and subsequent popes ${ }^{6}$. These were both documents under which organization and participation in performances were banned, acts of condemnation of the battles, threat of excommunication, and on the contrary legal acts officially restoring the corrida to plaza de toros and even pop-

but also in the very perception of the former Iberians. For decades, the culture of indigenous people merged with the influx of culture, especially Roman culture, which meant that the newly created mosaics gained crucial importance in the context of beliefs, traditions and rituals. The symbolism of the bull was also subject to this process.

4 The tendency to separate the clashes with the bulls fought by the aristocracy and other social strata appeared in the $13^{\text {th }}$ century, while the difference in how they were conducted was focused on fighting on horse (nobility) or on foot (people).

${ }^{5}$ Declared support and promotion of the corrida by Spanish kings, among others: Philip II, Philip III or Philip IV, and the complete abolition of its practice by Philip V or Charles III, as well as consent to its organization on the part of Ferdinand VI only in such a case when their nature is charitable, while Ferdinand VII lifted his original ban on the organization of tauromachic spectacles in Spain to allow it to be staged by La Casa de Caridad or the Charity House in Barcelona, which gave the foundation to the construction in 1834 of El Torín - one of the four plaza de toros in Barcelona.

${ }^{6}$ The papal edict of Pius V from 1567 De Salute Gregis, as well as the edict of George XIII lifting the ban of corrida Nuper Siquidem, who initially did not express any support for it or the ban on organization issued by Pope Sixtus V. 
ularizing it by the rulers themselves ${ }^{7}$. Such great interest in tauromachic fighting indicates the importance of the phenomenon in various areas of Spanish life. Furthermore, it should be emphasized that the issue of corrida de toros has almost always aroused extreme positions and has been outlawed and restored to grace over the centuries. Confirmation of the differences in its perception are also numerous parliamentary debates in the $19^{\text {th }}$ century, during which anti-tauromachic environments ${ }^{8}$ sought to marginalize the spectacle or ultimately abolish it.

The strength of impact of corrida de toros was also appreciated by General Francisco Franco, who tried to give a new quality to bullfights. During the continuance of dictatorship, it became known as Fiesta Nacional, or the National Day, what is more, it also gained sanctioning under the Spanish Rights announced in 1945. It constituted a set of norms, rights and privileges dedicated to all citizens, assuming that they would not be directed against the integrity of the state. Thus, the regime applied the corrida as a tool of national integration and an important element of the unification and centralization of Spain. It was the period of the Frankist regime and the instrumental use of numerous factors, phenomena, mechanisms, including those from the sphere of religion, sport or culture, has exacerbated relations between the political centre and the periphery, making of the above-mentioned elements of the political game, the implications of which can be seen especially in the era of escalating the Spanish-Catalan conflict. It is worth recalling that a similar mechanism was used by Franco in the case of rivalry between football teams: Catalan FC Barcelona and Real Madrid. The confrontation on the pitch was supposed to become an alternative to real political struggle, and at the same time be a safety valve, while the stadium would be a place of escape of negative emotions rising against the dictatorship.

In this light, it is necessary to recall Franco's main slogan, i.e. “ $E$ Españauna, grande y libre!" or "Spain one, great and free!". Therefore, the regime did not even allow discussions on regional differences, including cultural ones, and the existence of Spanish nationalities (Myśliwiec, 2014: 129), which was exemplified by lifting the autonomy of individual regions ${ }^{9}$, or a ban on using native languages. Furthermore, it is worth noting that in the program "Nation - Unity - Empire" the second point indicates that "Spain

7 Among others King Philip V took direct part in the corrida, however participation in the fight confirmed his belief that the organization of the corrida should be limited, which resulted in an appropriate edict prohibiting the participation of horses in it, which by nature eliminated the possibility of participation in the show of the nobility and aristocracy, and thus changed its character, since the main role began to be played by the toreadors who fought on foot, and the nobility was forced to use long spades, hence the name of the picador.

8 Groups opposed to the organization of bullfighting, commonly referred to as antitaurinos. The adversaries of the corrida also establish formal organizations, such as Asociación Nacional Para Bienestar de los Animales (ANPBA). It is no different in the case of supporters (aficionados), e.g. Unión de Federaciones Taurinas de Aficionados de España (UFTAE).

9 Except Nawarra. Even though. Franco referred to the Karlist ideology, where the leading principles were: God - Homeland - Local Rights - King or more generally: God - King - Fueros, did not allow the possibility of decentralization. 
is the unity of destiny of the nation. [...] All separatism is a crime that we cannot forgive" (Dobrzyński, 1975: 39).

The adjectives that make up the dictator's motto find their meaning within the framework of the identity system, which modeled 'Castilianity' and rejected everything that was different within and outside Spain, and thus the term 'one' referred to the Castilian unity of Spain, as a result excluding those elements that were, for example, Catalan or Basque in nature. On the other hand, they predestined those factors that represented (or allegedly represented) or reflected the Spanish people (García Morente, 1961: 48, $238)^{10}$. In turn, 'greatness' referred to the ideas of Spanish greatness, which was rooted in the conviction of the nobility of Castilian minds. In parallel, the adjective grande was to erase the humiliation of Spanish imperialism, build Spanish national pride and morality, and therefore Spain would become a spiritual reserve of the West. The term 'free' was used in a similar tone, which was to sanctify the role of Franco as a saviour and defender against the evil of the world, that is in his opinion: communism, socialism, liberalism, separatism, Jews etc. At the same time, 'freedom' was to manifest itself as a symbol of national independence in relation to the omnipotence of European countries. The Frankist definition of Spain as a 'national syndicalist' state indicates the regime's orientation towards building a nation state, which a natura rei meant eliminating elements of culture, tradition, customs, history or a regional language.

It is worth noting that the dictator sought to achieve national unity through religion, laying the foundations for an integrally Catholic state existence, drawing in its essence from the doctrine of nacional catolicismo. He sought for common and differentiating points in sport. Furthermore, Franco skillfully used such cultural artifacts as e.g. dance, and in this place the dichotomy between Spanish flamenco and Catalan sardana, banned during his reign or even corrida de toros and the meaning of bull as a synonym for Spanishness.

\section{The Catalan-Spanish conflict over the corrida}

Undeniably, Catalonia has for centuries been associated with bullfighting in the social, cultural and economic sphere, but also especially in recent decades politically. For hundreds of years, has been cultivated, among others, the tradition of correbous (running with bulls on city streets) ${ }^{11}$. It was in this region that some of the largest and most profitable plaza de toros were created, including La Monumental ${ }^{12}$. The last bullfight in Catalonia took place in the mentioned arena on September 25, 2011 (Bullfighting in Barcelona to end with Catalonia ban, 2011). The autonomous community is also famous for

10 The dictator avoided using the concept of 'nation', replacing it with the terms 'people' or 'homeland', because the first of these was symptomatic of the narrative used by representatives of peripheral nationalisms.

11 In this case, the show does not end with the death of the animal. As indicated by Juan Segura Palomares, there is evidence that this type of tradition was present in Cardona in the $15^{\text {th }}$ century (Segura Palomares, 1990: 190).

12 In 2007, the legendary matador José Tomás decided to return to participating in the arena. 
one of the oldest fighting arenas in Spain, including Plaça Clarà in Olot erected in 1859 or plaza de toros in Figueres built in 1894, while in 2006 the arena in Girona, which was founded in 1897, was demolished. At present, one of the most famous former bullfighting arenas is Arenas de Barcelona located in the heart of Barcelona, on the Plaza de Espana. There were disputes around the arena as to its development after the ban on organization of this type of shows. One of the projects involved transforming the facility into the largest mosque in Europe. This concept was strongly supported by foreign investors, including Saudi Arabia and Qatar. Ultimately, the opposition of Catalans, especially the inhabitants of Barcelona, resulted in the creation of one of the largest shopping centres in Western Europe.

Furthermore, Catalonia is a homeland and/or has educated many matadors and bullfighters; furthermore, the Spanish tycoon in the bull fighting business - the Balañá family - came from this region. One of the most important and influential businessmen in this area was Catalan, Pedro Balañá Forts, the owner of cinemas and theater, and above all four plazas de toros, i.e. the aforementioned La Monumental (since 1947), Arenas de Barcelona, fighting arenas in Majorca and in Jaén (Catà, 2018). However, it is worth emphasizing that corrida de toros has never enjoyed such a rich tradition and popularity as, for example, in Andalusia, Castile - La Mancha or Madrid.

Anti-tauromachic activities in Catalonia date back to more distant times than 2010, when they became the next level of political conflict between the region and Spain. In 1988, by a resolution of the Catalan Parliament regarding the protection of animal rights, the community authorities severely limited the possibility of organizing shows involving bulls, especially corrida de toros on portable battle arenas, as well as in the aspect of building new permanent plazas de toros (Ley 3/1988, de 4 de marzo, de Protección de los Animales, 1988). However, 11 years later in Catalonia, children under 14 years of age were banned from entering the arena, even when they were under adult supervision. In 2011, a similar ban was introduced in Galicia for children under 12 years of age, which was motivated by the well-being of children whose contact with violence could give birth to later pathological attitudes, as well as considerations of humane treatment of animals.

Another manifestation of the attempt to eliminate the corrida from the Catalan space was the overthrow in 2003 of Osborn's only bull ${ }^{13}$ on one of the regional highways. These activities were attributed to Catalan nationalists (Brandes, 2009: 787).

The announcement of Barcelona ${ }^{14}$ as an "anti-tauromachic city" (ciudad antitaurina) can be considered a turning point in the analyzed aspect. The decision of the city council was a pioneer step in this respect, which found its continuation not only in the activities of the local authorities of Catalan cities and villages, where by 2010, 37 centres had taken this initiative (Brandes, 2009: 787), but also in the whole monarchy, e.g.

13 Initially, the figure was a form of brandy advertising produced by the Andalusian company and placed in almost all Spanish autonomous communities, but over time it became a symbol of all of Spain.

14 There were once three fighting arenas in this city. 
in 2011 Cangas (Galicia) proclaimed itself "a city without a corrida and a city friendly to animals" (Skowrońska, 2011: 192).

As a result of the above actions, as well as the increasing public awareness in the aspect of animal rights protection in Spain, the number of viewers of corrida de toros, as well as the number of animals taking part in the competition, decreased significantly. It is worth emphasizing that this was one of the biggest decreases in popularity of the corrida over 30 years. For example, in 2009 there were 1,848 bullfights and other shows with the involvement of bulls in which 10,247 of these animals participated, which was a decrease of $16.88 \%$ compared to 2008 and 29.52\% from 2007 (Los toros en España: 1.848 corridas, 10.247 toros lidiados y 8.301 toreros, 2010). At the same time, given the number of organized corridas de toros in the Spanish autonomous communities, where the show enjoyed the greatest popularity, i.e. Castile-La Mancha or Andalusia, a clear downward trend can be indicated. In 2008, 2013 and 2015, the following was organized in the first mentioned region, respectively: 481, 69 and 54 bullfights, while in Andalusia: 405, 90 and 80. The same tendency, albeit at a lower intensity, was present in the autonomous communities, where the corrida was not very popular, among others in Asturias or Cantabria. In Asturias, the following were organized in the years under consideration: 7, 5 and 5, while in Cantabria: 18, 6 and 7 tauromachic performances (ZiółkowskaKuflińska, 2017: 174). Given that since 2008 the monarchy has been struggling with a deep economic crisis, it can be concluded that in the era of economic collapse and immediately after it, the Spaniards largely gave up allocating part of their household budget for participation in such performances. This was associated with a major recession on the Spanish market when it comes to the tauromachic industry, in which supporters of the corrida saw a partial remedy for the growing unemployment during the economic crisis, in the form of the possibility of creating a large number of new jobs and the stimulation of, among others, such branches as tourism. As it is visible, the downward trend was not only the domain of Catalonia, but of the whole of Spain, and speaking of the issue more broadly, the widely declared need to protect animals, which has been present in Europe for several years, was even more pronounced.

On this ground, it is necessary to point out that in 2002 a constitutional provision on the protection of animals was introduced in Germany, while as early as 1998 Austria prohibited animal breeding for fur. In the same year, the Swedish government comprehensively and restrictively regulated the issue of animal rights protection by means of the so-called Lex Lingren. On the other hand, United Kingdom is famous for one of the most stringent legal regulations in Europe in the field of animal rights protection, which include, among others, proper living environment or diet, the prohibition of fighting, but also provides for high penalties, including imprisonment, for animal abuse. Moreover, the British government announces strengthening of the law in connection with the planned withdrawal of Great Britain from EU structures. A similar tendency is noticeable, among others in Italy or Portugal. In Poland, from 1928, there were legal pro- 
visions regarding animal abuse, while the Act of 21 August 1997 on the protection of animal rights explicitly recognizes animals as living beings and capable of suffering. In this way, the previous perception of animals through the prism of things was rejected. Surprisingly, the dereification of animals in France and Portugal was only made in 2015 and 2017, respectively (Wlaźlak, 2019: 97-102). The cited examples confirm that in the European arena the issue of animal rights protection occupies an important place, with a clear tendency to strengthen the rules.

Given the above, it should be noted that Spain has only recently been trying to implement the European model in the field of protection and humane treatment of animals, which is confirmed by introduction at the end of 2017 of the law introducing the legal deprivation of animals of the status of things and granting them certain quasi-legal subjectivity. According to Katarzyna Wlaźlak, these changes result from the growing awareness among the society or its greater empathy towards the fate of animals, although transformations in the mentality of the Spaniards have not yet allowed for the delegalization of corrida de toros, and the antagonisms between aficionados (the supporters of the corrida) (Ziółkowska-Kuflińska, 2019: 203-213) and antitaurinos (the oppononets of the corrida) are still vivid (Wlaźlak, 2019: 105-106). However, this polarization has clearly increased in recent decades. For the supporters, it is an art that captures the beauty of a man's fight with a wild animal, while opponents emphasize the barbaric and anachronistic nature of the phenomenon. There is no doubt, however, that in terms of the perception of the corrida in many cases there has been a reevaluation and change in outlook, and moral, ethical or religious norms have become equally important to legal norms.

The different perception of the spectacle of bullfighting by Spanish society is a kind of confirmation of its heterogeneity. Some of the autonomous communities have decided to ban the organization of bullfighting (e.g. Canary Islands), while others are considering this option (Galicia), although the national legislator has not explicite agreed in this matter. In general, the Spanish central authorities stand for the protection of centuriesold tradition. Still during the rule of the party Partido Popular in 2013, Cortes General adopted a resolution establishing bullfighting performances as an intangible cultural heritage in Spain (Ley 18/2013, de 12 de noviembre, para la regulación de la Tauromaquia como patrimonio cultural, 2013). In the same year, El Plan Estratégico Nacional de Fomento y Protección de la Tauromaquia - PENTAURO was adopted, or a national plan to protect and promote tauromachic traditions (Ministerio de Cultura y Deporte, 2013), whereas in the previous year broadcasts which had been abolished in 2006 reintroduced the corrida to public television. Furthermore, Spanish decision-makers are striving to enter the show on the UNESCO World Heritage List, however, as Wlaźlak rightly points out, it is difficult to expect that an organization that promotes the protection of animals and their dignified treatment, and has also adopted, among others, the Universal Declaration on Animal Welfare, would welcome the Spanish request (Wlaźlak, 2019: 105-106), thus denying its strategic goals. 
In 2006, an intensified debate la reformataurina took place in Spain. Its initiator can be considered the then Minister of the Environment Cristina Norbona, who proposed introducing changes aimed at stopping the killing of bulls on plazas de toros. Obviously, the reform proposal polarized not only the Spanish political scene, but also sparked debate in the mass media and the Internet (Ziółkowska-Kuflińska, 2016: 156). Its intensity, as well as the notorious appearance of the issue of the corrida, both in the context of delegalization and better legal legitimacy during election campaigns, on the one hand indicates the importance of the spectacle as an identity and cultural factor of the Spaniards, as well as a significant element of the political game, and for many is associated with the need to protect animal rights.

Important pressure groups in the central and regional arena regarding the delegalization of corrida de toros have become animal rights activists, the so-called animalistas. It is due, among others, to the involvement of one such group called Prou! that signatures for a petition were collected, whose signatories have opposed the fights against bulls in the autonomous community (Tkac, 2014: 148). This social initiative was submitted to the Catalan Parliament in 2008, which caused almost two years of debates, disputes, protests, demonstrations for or against its implementation, however, the most important matter in the light of the conducted analysis was that all these activities were concentrated on two planes, for obvious reasons, the first concerned animal rights, while the second regarded Catalan identity and the issue of self-identification of Catalans, i.e. in fact a political element.

The intensity of the dispute is illustrated by the statements of regional politicians during parliamentary debates, where among others a member of the $\mathrm{CiU}$ (Convergencia $i$ Unió) Josep Rull wanting to emphasize the ban on the corrida in order to protect animal rights and not use it as a political tool, reminded that intellectuals such as Antonio Machado ${ }^{15}$, Lope de Vega ${ }^{16}$, Santiago Ramón y Cajal ${ }^{17}$ and Jacinto Benavente ${ }^{18}$ were in favour of outlawing the show for building a "better country". In opposition to this, derived from the People's Party of Catalonia (PPC) Rafael Luna said that everything that is not exclusively Catalan raises concern among the Catalanists. A similar position was expressed by the then President Generalitat José Montilla Aguilera (Tkac, 2014: 148). Considering the fact that in this period a large part of the politicians from the Federation of $\mathrm{CiU}$ clearly radicalized their views to move from positions of moderate modern nationalism to a manifestly independentist stance in the near future, i.e. supporting the independence of the region, the narrative of the Catalonian circles regarding the corri-

\footnotetext{
15 Spanish poet and politician, and activist on the republican side during the Frankist regime.

16 Spanish writer from the turn of the $16^{\text {th }}$ and $17^{\text {th }}$ centuries. Author of numerous dramas, sonnets, as well as short stories and comedies.

17 Neuroanatom, Spanish histologist and neurobiologist, Nobel laureate in medicine (1906, together with Camillo Golgi).

18 Poet, essayist, and Spanish playwright. In 1922, he received the Nobel Prize in literature.
} 
$d a$ could testify to the connection of the show with identity issues, and moreover, with its instrumental use.

The last of the mentioned areas has gained even more emotional impact with the announcement of the judgment of the Spanish Constitutional Court in the matter of the Statute of Autonomy of Catalonia of 2006, which was issued on June 10, 2010. According to many Catalans, it violated their sense of identity and at the same time dissimilarity from other residents of Spain. One of the crucial issues was the lack of confirmation in the document that the Catalan community was recognized as a nation.

At the end of July 2010, when pro-independence demonstrations and dissatisfaction with the ruling of the Tribunal were tormenting the region, the Assembly of Elected Officials adopted the ban of corrida de toros with a ratio of votes: 68 for, 55 against and 9 abstain ${ }^{19}$. It entered into force on January 1, 2012 and included these bullfights, which were accompanied by inflicting suffering on animals through the use of tools such as spades, banderillas or swords, and/or would eventually end in the death of the bulls.

In the light of the political conflict between Catalonia and Spain, the vote itself seems particularly substantial. The PSC and CiU decided not to introduce party discipline when casting votes. It is symptomatic that out of 68 votes supporting the implementation of the above ban, 65 belonged to deputies from CiU, ERC (Esquerra Republicana de Catalunya) and ICV-EUiA (Iniciativa per Catalunya Verds-Esquerra Unida i Alternativa) or groups with nationalist, independentistic or autonomous provenance. Only seven members of this party voted against the ban. All derived from the CiU. Three PSC politicians also supported the delegalization of the corrida. Other Catalan socialists and deputies from the PPC and Ciudadanos (Cat. Ciutadans or Ciutadans-Partit de la Ciutadania) which is a block of unionist parties. The above voting result is very eloquent when one takes into account the fact that in this period power in the region was exercised by a three-party coalition (tripartit): PSC-PSOE, ERC and ICV-EUiA with the President at the forefront Generalitat José Montilla Aguilera, while the opposition was the CiU federation formerly ruling in Catalonia for many years as a coalition and then a federation. There is a clear discrepancy between government/parliamentary allies, and at the same time a common position of some of them with $\mathrm{CiU}$, which at this stage could indicate an attempt to build a common independentist front, especially since in the near future, i.e. on November 28, 2010, early regional elections were announced. In addition, the nature of the groups themselves is also eloquent, since ethno-regional and regional formations, i.e. entities very strongly associated with Catalonia voted for the ban of the corri$d a$, while the parties with their mother parties at the central level voted against delegal-

19 An interesting analysis of press reports in Spanish dailies (nationwide, in dailies: "El Mundo", "El País", "ABC"), Catalan (e.g. "Avui", "El Periódico de Catalunya", "La Vanguardia") and the press in Salamanca ("El Adelanto", "La Gaceta", "Tribuna") in the context of the vote in the Catalan Parliament to prohibit the corrida using the HJ-BIPLOT method is presented by José David Urchaga Litago, Noa María Carballa Rivas and Aurora García González (Urchaga Litago, Caraballa Rivas, García González, 2017). 
ization, so their interest, in this case the Spanish interest in general, was not to abolish the spectacle, which many Spaniards see as the indisputable heritage of Spanish culture.

At the same time, the distribution of votes, as well as the party colors, represented by deputies advocating a ban may indicate that political motives have prevailed, thus identity issues have taken precedence over the need to protect animal rights. However, as a rule, the opponents of tauromachia did not see as significant the motives of political decision-makers, but rather their target effect - the abolition of corrida de toros. Moreover, it can be concluded that the mood prevailing at the time in Catalonia after the announcement of the Court's judgment as well as the demonstrations of hundreds of thousands, and some data speaking of as many as more than two million participants, influenced politicians' decisions to a greater or lesser extent. The majority of votes in favour of the delegalization of the corrida and almost unanimity, given the additional lack of party discipline during the vote, suggests that nationalist and independentist groups may be guided by the desire to strengthen fet diferencial, and not the declared animal welfare. Thus, another element differentiating Catalonia and Spain was established, which de facto meant strengthening for the Catalan identity. There also appears a problem as to the arbitrary statement by politicians of which element is and which is not Catalan.

In the above approach, the protection of animal rights would not be an autotelic goal, an end in itself, an overriding value, but only a slogan used in an instrumental way. The confirmation of this mechanism can be considered the adoption a few months later by the Catalan Parliament of a law aimed at protecting and promoting Catalan correbous (Donlon, 2014: 67-68).

The constructed dichotomy included another very important aspect, namely the concept of Catalonia promoted by Catalans and independentists as the most European region among the autonomous communities in Spain. In this sense, the Catalan people as modern, open, pro-European and tolerant has been juxtaposed with the rest of Spain, which appears in the Catalan narrative as parochial, closed and defends barbaric traditions that hit EU regulations and a course on deepening animal rights protection adopted by most countries of the old continent. Therefore, regional decision-makers not only deepened the awareness of Catalans as a separate nation with their own traditions, but also developed a way to expose the Catalan problem internationally.

There is a number of voices where the desire to ban the organization of tauromachic shows is motivated by ethical and moral considerations, which are associated with Catalan identity, especially in the context of the long tradition of acting as an ombudsman for animal rights, including the concept of a region without circuses with animals or the Barcelona tradition of prohibiting the sale of blind birds on street stalls, as well as placing animals in storefronts for sale (Cano-Herrera, 2010).

The position of the then Prime Minister of Spain José Luis Zapatero is also substantial. In order not to risk the accusations of unjustified limitation of the affirmation of regional differences, and at the same time not to fuel the growing independence mood in 
Catalonia, which threatened a further escalation of the crisis of relations between Barcelona and Madrid, he did not decide to block the entry into force of the ban. Moreover, he appealed to the Spaniards to respect the decision of the Catalans in the name of respecting the law of regions in an autonomous state (Wlaźlak, 2017: 40) and to stop politicizing it. It is also worth adding that during the reign of Prime Minister Zapatero and during intensive debate on the subject of the corrida, responsibility for the development and protection of such shows was transferred from the Ministry of the Interior to the Ministry of Culture (Donlon, 2014: 67).

Another fact that supporters of delegalizing the corrida de toros in Catalonia have eagerly cited was the ban introduced in the Canary Islands already in 1991. It should be mentioned that it did not arouse such great emotions in the country, since the fight with bulls had not enjoy popularity on the islands for years, and the desire to in this way emphasize their diversity by the population living on the archipelago from mainland Spain was considered in geographical terms and a considerable distance from the centre. Moreover, it was pointed out that bloody spectacles were not popular among tourists who were increasingly choosing this destination (Adamus, Paluch, 2013: 52). In the area of law enacted by regional authorities on the corrida, it was an innovative activity, although it was not without controversy related to cockfights. When comparing the cited examples of the introduction of bans, several significant differences should be indicated, above all the time in which they were introduced. At the beginning of the 1990s, independentism was not very popular in Spain, except for the Basque Country, where it functioned as both a thought and a socio-political movement, and was also implemented by the terrorist activities of ETA. In Catalonia, moderate Catalans led the way, while the independentists were not a significant political force. The idea of independence of the region itself was present at the level of political thought, and independentism as a socio-political movement was born only at the turn of 2005/2006, in connection with work on the project, and then adopting the new Statute of the Autonomy of Catalonia in 2006. Hence, the removal of corrida de toros in the Canary Islands was interpreted in terms of regional identity, while the actions of Catalan decision-makers sought political motives and were interpreted as an attack on the integrity of Spain.

The decision of the Catalan Parliament on delegalizing the corrida was appealed to the Constitutional Court of Spain on October 28, 2010 by the People's Party (PP). The party politicians, as well as the aficionados, pointed out the need to examine the compatibility of the Catalan provisions with the letter of the Spanish Constitution in the context of "freedom of access for all Spaniards to culture, that is artistic creativity and freedom of entrepreneurship" (Ziółkowska-Kuflińska, 2016: 156).

The verdict in this case was issued on October 20, 2016. The Constitutional Tribunal stated that the Catalan Parliament had no legal basis to introduce the said ban, while pointing out to the constitutional right of Spanish citizens to use cultural goods. In other words, according to the ruling, Catalan decision-makers deprived the inhabit- 
ants of the region to actively and voluntarily use cultural goods guaranteed by the Spanish Constitution. The Tribunal also emphasized that there was a violation of the state's competence in the matter of protecting cultural heritage, i.e. the corrida. However, the autonomous community only has competence in the field of shows and animal protection. This judgment may arouse controversy, given the fact that autonomous communities often have a broad range of activity and independence, also in terms of legislation in the field of culture (Wlaźlak, 2019: 110). It is worth recalling here that the decentralization of Spain and the adoption of the model of the state of autonomous communities (regional state) has given Generatlitat the possibility of successively taking over competence in their own affairs, which the Catalan political elite eagerly took advantage of. The catalogue of entitlements consists of three categories, i.e. competences that can be transferred to autonomous communities, shared (joint) competences and exclusive state competences (Kozłowska, 2012: 108). The legislator emphasized that in cases clearly not restricted to the state, based on the relevant provisions contained in the statute, they may fall under the jurisdiction of the autonomous authorities. In this context, the case law of the Tribunal indicating the real rather than the apparent power of autonomy seems particularly important (Wlaźlak, 2019: 110). However, the presumption of competence lies with the state authorities. Hence the significance of the statute itself. Failure to regulate matters in this document as part of exclusive competence, in the event of a dispute, was transferred to the level of powers of the central authorities, but this state law is to complement Community law.

As Wlaźlak observes in a situation where the Spanish Constitution clearly indicates that the differentiation of community statutes cannot imply economic and social privilege, this situation is incomprehensible, where the socio-economic specificity of the Canary Islands is a sufficient basis for the introduction of effective delegalization of the practice of tauromachia or the ban on organizing the festival Toro de la Vega in Castile-Leon, introduced by regional authorities in 2016 due to the declared desire to avoid public killing of animals, and on the other hand to limit another region in this respect, e.g. Catalonia. What seems interesting is that the aforementioned ban in Castile-Leon was maintained by the Higher Court of the region in 2018, and a year later by the Supreme Court (Wlaźlak, 2019: 110).

It can, therefore, be concluded that the Constitutional Tribunal granted the complaint of the corrida supporters and analyzed its delegalization in Catalonia from the perspective of competence, however, there was a clear contradiction and inconsistency with previous case law, as well as the line maintained in the future (Mulá, 2018). This is confirmed by the Balearic autonomous parliament's adoption of a ban on fighting bulls, admittedly the corrida still takes place there, but in a completely different setting: without suffering, pain and the ultimate death of the animal. The shows themselves were limited to a dozen or so minutes, and the issues of transport, keeping and veterinary care over bulls were precisely regulated. After the introduction of the ban in the Balearic Islands, 
the central authorities announced that they would raise this issue before the Constitutional Tribunal in order to examine compliance with the Basic Law and the regulations on bullfighting (Wlaźlak, 2019: 112). Time will tell whether a quite groundbreaking and bold solution of the autonomous authorities will simultaneously set a new direction in case law and Spanish state legislation.

In the context of the undertaken analysis, it is advisable to mention one more plane of Catalan-Spanish competition - the symbolic sphere. The multiethnic, multinational and multicultural population of the monarchy often abandons traditions, which once did not arouse on controversy in favour of cultivating regional customs or even proposes its own 'invented traditions' in order to be able to put them in opposition to the Spanish ones, understood as foreign, imposed by the centre promoting 'Spanishness'. An exemplification of the operation of such a mechanism is the building of a strong national identity by the Catalans, and a peculiar counter-symbol to the Spanish bull would be the recognition of the Catalan donkey ${ }^{20}$. This is an example of the creation of a new symbolism. The donkey, which has gained such great popularity that it was adapted as a symbol of the entire area, in a metaphorical view is to identify the character traits of the Catalans themselves, i.e. wisdom, patience and persistence ${ }^{21}$, which refers to the aspirations for independence (Kozakowski, 2014). Although the prototype of the donkey was created only in 2004 in the form of a sticker that was to alert about the threat of extinction of the animal, it quickly adopted itself as an attribute not only of independentists. Ruccatalà (the Catalan donkey) has also become synonymous with dying Catalan culture and language that require special care. The eloquent representation of the Catalan character seems even more evident in the situation of juxtaposing a donkey with the symbol of Spain - a bull, emanating strength, but at the same time considered a thoughtless animal, if not stupid. Of course, modern-day bull worship in Spain is closely associated with the corrida.

\section{Conclusions}

The strong national identity of the Catalans, as well as Catalanism that arose in this area, followed by independentism, make the ties between Spain and the autonomous region change their character. The crisis in Spanish-Catalan relations which has been deepening for several years now takes on new dynamics. In order to emphasize their diversity and at the same time build their own identity, Catalans willingly use the exhibition of elements that differentiate the autonomous community from the other components of the monarchy. In parallel, what commonly functions in the socio-cultural or political sphere as 'Spanish', and thus foreign, is often replaced by a 'Catalan product.' This is

\footnotetext{
${ }^{20}$ In the case of Galisians, this role is played by a cow.

${ }^{21}$ In Polish culture, the donkey most often gains pejorative qualities, while in the minds of the Spaniards it has a positive valuation and is considered a useful, hard-working animal, which once gave prestige to its owners.
} 
the case with the ban on corrida de toros by the Catalan Parliament or the adaptation of a new symbol of the region - a donkey. It can be concluded that the dispute related to this issue, followed by the judgment of the Spanish Constitutional Court in this aspect, has primarily political overtones, and only then raises the cultural, economic, ethical or moral aspect (aimed at protecting animal rights). This is indicated by both regional and central decision-makers. What seems particularly important, the instrumental use of the corrida confirms that the conflict between the Spanish centre and the periphery is multidimensional, multifaceted and manifests itself in both overt and disguised actions, making it particularly difficult to resolve.

\section{Bibliography}

Adamus J., Paluch M. (2013), Corrida de toros jako atrakcja turystyczna, “Turystyka Kulturowa”, No. 9, pp. 47-72.

Barbarzak D. (2016), Rzymskie igrzyska i hiszpańska corrida. Rys porównawczy obu tradycji na wybranych przykładach, "Symbolae Philologorum Posnaniensium Graecae et Latinae", No. XXVI(2), pp. 19-43.

Bullfighting in Barcelona to end with Catalonia ban (2011), "BBC News", 25.09.2011, https://www. bbc.co.uk/news/world-europe-15050706 [access on: 27.10.2019].

Caillois R. (1997), Gry i ludzie, Warszawa.

Cano-Herrera M. (2010), Tauromaquia e identidadmoral de Cataluña, "Derecho Animal. Forum of Animal Law Studies", No. 1(3), pp.1-10.

Catà J. (2018), Fallece a los 93 años el empresario Pedro Balañá, "El País”, 16.01.2018, https://elpais.com/ cultura/2018/01/16/ actualidad/1516122992_542653.html [access on: 27.10.2019].

Daza J. (1999), Preciosmanejos y progresos del arte del toreo, Sevilla.

Dobrzyński R. (1975), Błękitne imperium gen. Franco, Warszawa.

Donlon J.G. (2014), Bayou Country Bloodsport: The Culture of Cockfighting in Southern Louisiana, Jefferson.

García Morente M. (1961), Idea de la Hispanidad, Madrid.

Kozakowski M. (2014), Osioł osłu nierówny. Wizerunek osła w katalońskiej symbolice, "Pracownia Kultury", No. 4, http://www. laboratoriumkultury.us.edu.pl/?p=30659 [access on: 28.12.2017].

Kozłowska M. (2012), Model państwa regionalnegow Unii Europejskiej: we Włoszech i w Hiszpanii, Wrocław.

Ley 18/2013, de 12 de noviembre, para la regulación de la Tauromaquia como patrimonio cultural, Boletín Oficial del Estado número 272, 13 November 2013, https:/www.boe.es/diario_boe/ txt.php?id=BOE-A-2013-11837 [access on: 11.11.2019].

Ley 3/1988, de 4 de marzo, de Protección de los Animales, Boletín Oficial del Estado número 75, 28 March 1988), https://www.boe.es/eli/es-ct/l/1988/03/04/3/dof/spa/pdf [access on: 03.11.2019].

Los toros en España: 1.848 corridas, 10.247 toros lidiados y 8.301 toreros (2010), "La Vanguardia", 28.07.2010, https://www.lavanguardia.com/politica/20100728/53973695245/los-toros-enespana-1-848-corridas-10-247-toros-lidiados-y-8-301-toreros.html [access on: 03.11.2019].

Ministerio de Cultura y Deporte (2013), PENTAURO - Plan Nacional de Fomento y Protección de la Tauromaquia, http://www.culturaydeporte.gob.es/cultura/ tauromaquia/pentauro.html, [access on: 11.11.2019].

Mulá A. (2018), Análisis Jurídico, Antecedentes y Consecuencias de la Sentencia 177/2016, del Tribunal Constitucional, sobre prohibición de las corridas de toros en Cataluña, "Revista De Derecho Uned", No. 22, pp. 407-436. 
Myśliwiec M. (2014), Pozycja partii regionalnych w systemie politycznym współczesnej Hiszpanii, Katowice.

Segura Palomares J. (1990), Desafio al presente: Los toros vistos desde Cataluña, Madrid.

Skowrońska A. (2011), Corrida - walka czy okrucieństwo?, [in:] Kryminologia wobec współczesnych zagrożeń ekologicznych, edit. M. Kotowska, W. Pływaczewski, Olsztyn.

Tkac J. (2014), The Role of bullfighting and FC Barcelona in the Emancipation of Catalonia from Spain, "Revista de Humanidades", No. 23, pp. 137-156.

Urchaga Litago J.D., Caraballa Rivas N.M., García González A. (2017), Cobertura mediática de la prohibición de las corridas de toros en cataluña a través de un análisis multivariante HJ-BIPLOT, "Revista de Investigación Social: Investigarlo Local: Reflexiones, Métodos y Casos de Estudio", No. 9.

Wlaźlak K. (2017), Unidad de destino? Doświadczenia i wyzwania hiszpańskiego państwa regionalnego, [in:] Adóndevas, España? Przemiany polityczne w Hiszpanii i Ameryce Łacińskiej na przełomie XX i XXI wieku, edit. S. Dudra, Ł. Młyńczyk, R. Michalak, Zielona Góra.

Wlaźlak K. (2019), Spór o zakaz corrida de toros, "Prokuratura i Prawo", No. 6.

Ziółkowska-Kuflińska M. (2016), Otwarta arena. Spór o corridę de toros w Hiszpanii, Poznań.

Ziółkowska-Kuflińska M. (2017), Antropologia corridy de toros w ujęciu koncepcji Norberta Eliasa, [in:] ¿Adóndevas, España? Przemiany polityczne w Hiszpanii i Ameryce Łacińskiej na przełomie XX i XXI wieku, edit. S. Dudra, Ł. Młyńczyk, R. Michalak, Zielona Góra.

Ziółkowska-Kuflińska M. (2019), Aficionados na plaza de toros. Przegląd wybranych organizacji protauromachicznych w Hiszpanii, [in:] Unia Europejska w badaniach interdyscyplinarnych, edit. M. Potkańska, L. Wojnicz, D. Rdzanek, Szczecin.

Abstract: The Corrida de tores, as an important component of Spanish culture, has also been the subject of a dispute between the aficionados (supporters of the corrida) and the antitaurinos (opponents of the corrida) for centuries. Naturally, the spectacle has become an object of interest for researchers not only in the socio-cultural context, where it is becoming a spectacle full of artistry, accompanied by great emotions, or a tradition in some aspects resembling the Fiesta Nacional, but also becoming increasingly important on the political, moral and ethical level. The latter is related to the issue of animal protection and their humane treatment, while in the political dimension the links between the taurammatic tradition and the actions of political decision-makers are mainly analysed. Importantly, in the Catalan and Spanish public spaces, the corrida has become a national sporting role, with similar links to politics. In the light of the Catalan-Spanish antagonisms, this perspective is gaining particular importance, as evidenced, for example, by the flashback of football competition (Real Madrid FC vs. FC Barcelona) in the country under Francisco Franco's regime, where sporting competition became an exemplary political game.

The aim of the article is to analyze the dispute between politicians in Madrid and Catalanists and independents in the region in the context of the banning of the de toros corrida in Catalonia in 2010 and the reaction of the centre's decision making centre to these actions. Moreover, the motives for this ban are sought, whether they are of an autotelic nature - in this case, the protection of animal rights or whether they show the traits of instrumental use of tradition, de facto considered to be a "foreign", because Spanish, part of the rhetoric and real policy pursued by Catalan nationalists and independents in the era of radicalisation of the independence movement in Catalonia.

Keywords: Catalan-Spanish conflict, corrida de toros, Catalanism, Catalan independency, banning of corrida

Article submitted: 20.10.2019; article accepted: 20.11.2019. 